\title{
ITINERANT CURRICULUM THEORY. AN EPISTEMOLOGICAL DECLARATION OF INDEPENDENCE
}

\author{
Joao M. Paraskeva \\ UMass Dartmouth, USA
}

\begin{abstract}
Within the course of the twentieth century and within the context of broader complex social -local and global-issues, curriculum became a open political and ideological battle field, in which dominant and counterdominant groups re-escalate the animosity with sides basically assuming a 'taking no prisioners commitment'. The purpose of curriculum theory[ists] is to travel, to go beyond the limits, to move, and stay in a kind of permanent exile. A theory of non-places and non-times is, in essence, a theory of all places and all times. The curriculum theorist is a constant migrant, a permanent nomad of his own all multifaceted consciousness who experiences a series of [epistemological] events. Moreover, ICT pushes one to think in the light of the future as well as to question how can 'we' actually claim to really know the things that 'we' claim to know if 'we' are not ready specifically to think the unthinkable, but to go beyond the unthinkable and to struggle with its infinitude.
\end{abstract}

KEYwORDs: teory, curriculum, decolonialism, cosmopolitism, críticism, citizen, solidarity, epistemologies.

\section{TEORÍA CURRICULAR ITINERANTE. \\ UNA DECLARACIÓN EPISTEMOLÓGICA DE INDEPENDENCIA}

\section{RESUMEN}

En el transcurso del siglo xx y en el contexto de cuestiones sociales, locales y globales más amplias y complejas, el plan de estudios se convirtió en un campo de batalla político e ideológico abierto, en el que los grupos dominantes y contradominantes reavivan la animosidad con los bandos asumiendo básicamente un 'no asumir el compromiso de los prisioneros'. El propósito de la teoría curricular [curricularista] es viajar, ir más allá de los límites, moverse y permanecer en una especie de exilio permanente. Una teoría de no lugares y no tiempos es, en esencia, una teoría de todos los lugares y todos los tiempos. El teórico del plan de estudios es un migrante constante, un nómada permanente de su propia conciencia multifacética que experimenta una serie de eventos [epistemológicos]. Además, las teorías curiculares itinerantes (TCI) lo empujan a uno a pensar a la luz del futuro, así como a preguntarse cómo 'realmente' podemos afirmar que realmente sabemos las cosas que 'nosotros' afirmamos saber si 'nosotros' no estamos preparados específicamente para pensar lo impensable, sino ir más allá de lo impensable y luchar con su infinitud.

Palabras clave: teoría, currículum, decolonialismo, cosmopolitismo, crítica, ciudadanía, solidaridad, epistemologías.

DOI: https://doi.org/10.25145/j.qurricul.2020.33.03

Revista QurRiculum, 33; junio 2020, pp. 31-47; ISSN: e-2530-8386 
For centuries the poet has sung of his near infinitudes; the theologian has preached of his depravity and hinted of his participation in the divine; the philosopher has struggled to encompass him in his systems, only to have him repeatedly escape; the novelist and dramatist have captured his fleeting moments of pain and purity in never-to-be-forgotten aesthetic forms; and the [man] engaged in the curriculum has the temerity to reduce this being to a single term-learner. (Huebner, 1966, p. 10)

The struggle for the curriculum, since its emergence as a field of studies at the end of the nineteenth century, was always quite belligerent (Klibard, 1995; Tyack, 1974; Krug, 1969), with dominant and counter dominant groups and movements fighting over the whose knowledge should be (re)produced (Apple, 1979; Paraskeva, 2011). Within the course of the twentieth century and within the context of broader complex social -local and global-issues, curriculum became a open political and ideological battle field, in which dominant and counterdominant groups re-escalate the animosity with sides basically assuming a 'taking no prisioners commitment' (Paraskeva, 2011). However, at the sunset of the twentieth century, it was already visibile that the clashes between hegemonic and counterhegemonic movements with radical critical impulses and commitments, had triggered an involution (Gil, 2009). That is, the struggle between dominant and counterdominant educational and curricular movements created what I call "curriculum involution" (Paraskeva, 2018), a state of massive regression; that is, the dominant models were capable to impose as unique and completely destroy the counter-dominants, nor were the dominant ones able to impose themselves as dominants and dismantle the dominant ones. There was neither the emergence of a new human being nor the end of the old human being. There was no evolution in either direction. Somehow, we have the dangerous privilege to live a theoricide, which is not necessarily an absence of theory -a perpetual theoretical killing.

I argue that the best way to unblock such involution is to deterritorialize curriculum theory, which implies a commitment to fight for a different research platform, one that pushes research to a "level of instability, not stability, generating concepts also, in itself, unstable” (O’Brien \& Penna, 1999, p. 106). In doing so, a deterritorialized curriculum theory increasingly becomes an itinerant theory, a theory of nonspaces (Auge, 2003). In essence, one needs to assume a rhizomatous approach that sees reality beyond dichotomies, beyond beginnings and endings (Gough, 2000); an approach that breeds from the multiplicity of immanent platforms and, from its centerless and peripheryless position, defies the myth of clean knowledge territories (Deleuze \& Guattari, 1987; Eco, 1984). Such itinerant position should be seen as subversively transgressive. The "purpose of curriculum theory[ists] is to travel, to go beyond the limits, to move, and stay in a kind of permanent exile" (Said, 2005, p. 41). A theory of non-places and non-times is, in essence, a theory of all places and all times. The curriculum theorist is a constant migrant (Jin, 2008), a "permanent nomad of his own all multifaceted consciousness" (Pessoa, 2014, p. 113), who experiences a series of [epistemological] events (Khalfa, 1999). The itinerant theorist is a "real dinamogenus" (Gil, 2010, p. 13). Such migrant being and thinking 
situates the itinerant theorist; "it beckons us to recognize that how we perceive and experience the world (individually or communally), how we identify problems and name solutions, and how we locate ourselves in the world are all inseparable to the struggle for cognitive justice" (Darder, 2018, p. xI), thus helping to short circuit the functionalist trap that is sinking Western Eurocentric dominnat and the counterdominant platforms (Süssekind, 2017; Oliveira, 2017; Moreira, 2017).

In arguing for an itinerant curriculum theory (hereafter ICT), I am claiming an atypical epistemological approach that will be able to deconstruct the images of thought, thus re-thinking the utopia through re-utopianizing thinking fueling the emergence of radical collective and individual subjectivtities; ICT is a metamorphosis, exhibiting "a double purpose though; (a) to reinvent maps of social emancipation and (b) subjectivities with the capacity and desire for using them; that is no paradigmatic transformation would be possible without the paradigmatic transformation of subjectivity" (Santos, 1995, p. 482). In doing so, ICT brings back to the fore social imagination (Berardi, 2012) but within a pluriversal matrix.

Such an approach will unfold naturally into voluntary and involuntary creations (Merelau-Ponty, 1973). Furthermore, the curriculum worker and creator need to be seen as "an auctor, which is qui auget, or the person who augments, increases, or perfects the act (in fact), since every creation is always a co-creation, just as every author is a co-author" (Agamben, 2005, p. 76). To create, the theorist "needs a foothold" (Pessoa, 2014, 214), and the strength of such foothold comes from his/her "extraordinary exteriority" (Gil, 2010, p. 14), that is the "interior and exterior constitute a space of implosion" (Gil, 2010, p. 15). The core of ICT is the fact that it ferociously challenges any attempt of a bunker theory-practice or a bunker praxis. In examining the complex conundrum of the Portuguese identity, the great Mozambican born philosopher José Gil (2009) argues that identity matters are not detached from the cruelty of a "one and only one-dimensional way" (p. 38). That is, the cult of 'the one best theory-practice' "is intimately connected with all the commonsensical commonsense lack of evidence of so-called credible alternatives, that 'cocoonizes' the subject in invisible and visible bunkers" (Gil, 2009, p. 38). In a way, to upgrade Gil's (2009) arguments, a palpable 'selficide' is systematically produced by blocking 'truth' from itself and from the very own self, a self that can only exist 'in inner violence.' In fact, I argue that our field doesn't have a lack of identity, quite the opposite it has a healthy excess of identity (Gil, 2009). Thus, ICT is not a bunker theory (Gil, 2009); it works under a pluralistic conceptual grammar (Jupp, 2017, p. 4) "emphasizing (a) the coloniality of power, knowledge, and being; (b) epistemicides, linguicides, abyssality, and the ecology of knowledges; and, (c) poststructuralist hermeneutic itinerancy"; such pluriversal grammar allows to think "a prudent knowledge for a decent life" (Santos, 2007a) defending the epistemological as a political. In this context, ICT promises a sense of respect for epistemological diversity. While being an "occupying epistemology" (Santos, 2018, p. 2), its aim is not "to overcome the hierarchical dichotomy between North and South, but rathter to overcome such normative dualism" (Santos, 2018, p. 7). Thus, it is the claim of a just theory that sees the collective struggle for knowledge as a struggle that must go far beyond the Western epistemological platform. ICT is a 
clear appeal against the precariousness of any ossified and fixed theoretical position (Paraskeva, 2018). ICT walks towards knowledge emancipation, thus opening up the canon of knowledge regulation; it is not a great narrative of a great theory as "knowledge-emancipation does not aspire to a great theory, it aspires to a theory of translation that serves as an epistemological support for emancipatory practices" (Santos, 1999, p. 206).

It is not a great theory, it is only a theory -perpetually itinerant- of greater knowledge, fully aware that such greater knowledge, as Tse (2017) argues, is reachable only through a "full consciousness that everything is continually transformed inside and outside our mind" (p. 66). Itinerancy thus is not real, it's the real(ity). ICT is thus "an epistemic minga, a collective farming for the collective good" (Santos, 2018, p. 146). In this sense, ICT doesn't just face the outside (Gil, 2010, p. 16) as it is indeed the outside -but not an outsider-, yet steams discrete sensationism -the opposite of sensationalism - "the only reality is the sensation of consciousness" (Gil, 2010, p. 65). ICT is a wordily theoretical approach, it is the theory of palavrar. It is an attempt to build a theory "que palavre e não que diga" (Pessoa, 2014, p. 226). In this sense, the itinerant theorist is always mining the meaning (Williams, 2013), knowing fully well that what is around is rather more crucial than the dust, noise, and the grain provoked by the minining. Thus, an itinerant curriculum theory is inherently "an exfoliation" (Gil, 1998, p. 127) metamorphosis, a sill of infinite mournings" (Couto, 2008, p. 105), an anti- and post- "mechanotic" (Ahmad, 1984, p. 31) momentum that will seek to create "a powder, gentle, maneuverable, and capable of blowing up men without killing them, a powder that, in vicious service, will generate a life, and from the exploded men will be born the infinite men that are inside him" (Couto, 2008, p. 68). In such context, ICT is a "pluriversal polyphony, a polylectal rather than ideolectal conception of cultural and political imagination" (Santos, 2018, p. 12 ), so crucial in an era paced by the death of imagination. I argue for a "new form of political affirmation grounded in a global pluriversal epistemological visions and interests to be favored and courses of action to be followed that are sustained in people's history" (Popkewitz, 1978, p. 28).

The educational and curriculum theorist needs to be understood as an epistemological pariah, who is challenging and challenged by a theoretical path that is inexact yet rigorous (Deleuze, 1990). It is, as we will see later on, a theory of frontier and baroque, in a perpetual transitionality state (Santos, 1995). In this sense, an itinerant theorist is immersed in a metamorphosis "so perpetually incomplete that even dreams dislike because they have defects" (Pessoa, 2014, p. 126); so perpetually deep that it hurts the imagination (Gil, 2010, 86), it hurts the "physical brain" (Pessoa, 2014, p. 234). ICT is the perfect utopia because it is conscious of the imperfection of what is perfect, conscious of the perfection of the imperfection. Hence, being perfect contradicts being complete, and yet the theorist is thirsty for being complete leaving him/her in a perennial state of useless pain. ICT reflets a subject that when "he/she thinks sees him/herself in the process" (Pessoa, 2014, p. 73) and fully "understands that if one knew the truth one would see it" (Pessoa, 2014, p. 96). ICT "captures, vampirizes, and calls on the subject to complete it" (Gil, 2010, p. 29). Such an itinerant theory(ist) provokes (and exists amid) a set of crises and 
produces laudable silences. The theory(ist) is a volcanic chain, showing a constant lack of equilibrium, and thus is always a stranger in his/her own language. He or she is an itinerant theory(ist) profoundly sentient of the multiplicities of lines, spaces, and dynamic becomings (Deleuze, 1990). ICT thus echoes Huebner's (1966; 1959) challenges of a radically different semantology, thirstly seeking for a new language. With the term epistemicide, Schubert (2017) Paraskeva's ICT "enacts the call for new languages for curriculum studies" (p. 12).

ICT does try to say something to the field. It presents new terrains and theoretical situations. ICT participates in the complicated conversation (Pinar, 2000; Trueit, 2000) -that cannot bend under the yoke of Western academicismchallenging Western curriculum epistemicides and alerting us to the need to respect and incorporate non-Western epistemes. Pinar (2012, 2013) acknowledged the influential synopticality of ICT:

There are other discourses influential now, sustainability perhaps primary among them. Arts-based research is hardly peripheral. ... One sign is the synoptic text composed by João M. Paraskeva. Hybridity is the order of the day. Pertinent to the discussion is that even Paraskeva's determination to contain in one "critical river" multiple currents of understand-ing curriculum politically floods its banks; he endorses an "itinerant curriculum theory" that asserts a "deliberate disrespect of the canon" $(2011,184)$. In Paraskeva's proclamation, this "river" has gone "south" (2011, 186). That South is Latin America, where we can avoid "any kind of Eurocentrism" $(2011,186)$ while not "romanticizing indigenous knowledge" (2011, 187). Addressing issues [such as hegemony, ideology, power, social emancipation, class, race, and gender] implies a new thinking, a new theory ... an itinerant curriculum theory (Pinar, 2013, p. 64).

ICT, as new influencial discourse, as Pinar $(2012 ; 2013)$ put it, is highly relevant, Zhao (2019) argues, as it opens up the eugenic colonial sociabilities (Santos, 2018) built on "language, knowledge, culture and educational" cleansing of the South (p. 27). In this sense, ICT is "corazonar," that is to warm up reason, a reason that has been corazonada, and, thus, it "cannot be planned as it occurs out of joined struggles, building bridges between emotions' affections on one hand, and knowledges/reasons, on the other" (Santos, 2018, p. 101). It goes without saying how "spirituality is towing in corazonar converting it into a non-Western-centric form of insurgent energy against oppression and unjust suffering" (Santos, 2018, p. 100).

Such a theoretical course is defined by a cutting edge, a Malangatanian and Pollockian set of processes, not because it is abstract but because it is oppressive in its freedom. ICT is thus a theory of disquiet (Pessoa, 2014), challenging the "disquiet paralisis" (Gil, 2009, p. 20), yet knowing fully well that it is through disquiet that subjectivities emerge (Gil, 2009). It is not a sole act, however; it is a populated solitude. This itinerant theoretical path, claims a multifaceted curriculum compromise, and "runs away" from any unfortunate 'canonology.' ICT, as Darder (2018) unpacks, claims for a political praxis that "must be both epistemologically fierce and deeply anchored in the sensibilities of our subalternity -the only place from which we can truly rid ourselves of the heavy yoke of Western sanctioned tyranny, 
which has wrought bitter histories of impoverishment, colonization, enslavement, and genocide" (p. x).

Such an itinerant curriculum theory is an anthem against the indignity of speaking for the other (Walsh, 2012; Deleuze, 1990). ICT challenges the sociology of absences, as the only way to grasp "silences, needs, and unpronounceable aspirations questions" (Santos, 1999, p. 206); it challenges "how can silence be spoken without it necessarily speaking the hegemonic language that intends to make it speak? (Santos, 1999, p. 206); it is the curriculum praxis of the sociology emergences, as Santos (2018) would put it; an itinerant theory "of the sociology of absences and emergences; the former "would be geared to show the measure of the epistemicide caused by northern epistemologies, while the latter would be oriented to amplify the meaning of the latent and potentially liberating sociabilities" (Santos, 2018, p. 276), paving the way for a just pedagogy, one that foster southern epistemologies. In such sense, ICT is not an ortonimus theory, quite the opposite (Gil, 2010), it is a heterotheory. The theorist multiplies her/himself to feel her/his own individual and collective subject (Gil, 2010); to be sincere, the intinerant theorist contradicts himself every minute (Gil, 2010) as reality is massively contradictory. ICT is not a "diminished theory" (Pessoa, 2010, p. 230); nor it diminishes any other epistemological formation.

The itinerary theory(ist) is much more than an eclectic approach; it is actually profoundly (in)discipline, yet doesn't correlate with any disciplinary grid that ossifies Modern Western Eurocentric epistemological platforms. It "reacts against the vegetal academy of silence" (Pessoa, 2014, p. 270). ICT confronts and throws the subject to a permanent, unstable question, 'What is to think?' ICT is a metemorphoses of the endless multifarious epistemological "alphabet[s] of thought" (Gil, 2009, p. 25). It is actualy a loaf theory. In this sense, ICT "reads differently because it is written and spoken in a different way" (Gil, 2010, p. 20); ICT pushes one "to think differently, but also to learn differently and to better understand what it means to learn, and what does it mean to think" (Gil, 2009, p. 35). It is epistemologically radically different; it is a new epistemological logic, one of excess so crucial to deterritoralize and delink, but above all to reignite -in a radically way-the utopia for a just world.

Moreover, ICT pushes one to think in the light of the future as well as to question how can 'we' actually claim to really know the things that 'we' claim to know if 'we' are not ready specifically to think the unthinkable, but to go beyond the unthinkable and to struggle with its infinitude. In this contex, ICT challenges not just momentism (Paraskeva, 2011) or presentism (Pinar, 2004) but, contemporarysm (Paraskeva, 2011). In Gil's (2018) terms, "never has a time been so contemporary as to appear to embody much more than the contemporary time" (p. 404). One is no longer 'contemporary of'; one is simply 'contemporary.' In essence, everything has become contemporary. The yoke of the present-now -in which our field is sinking- is viral, a new barbarism that wipes out ethics of memory regarding a past that was always a future for a given generation at a specific point. Each 'now' is a 'now' of an absent past or future. Each 'present-now' is a 'present-now' of a 'particular now.' Devoided from a future reality -diluted witin the present- societal transformational impulses have been triggered by having the past as reference, and, commonsensically, one thinks about change in terms of "re-covering, re-building, 
re-habilitate" (Williams, 2013, p. 281). The human being produced by the democratic Cartesian matrix "leaves and exists for the pure present" (Badiou, 2011, p. 13), a present that is the only one, rather "the present of Europe" (Mignolo, 2018, p. 110). Modernity's present time, Mignolo (2018) advances, "was understood to be the only present, the present of Europe" (p. 110). As we are contemporaries of everything -past and future-, "everything is present, we are only 'contemporaries' because everything is contemporary and present" (Gil, 2018, p. 405). This dangerous cult of 'the contemporary' completely dilutes any utopian hypothesis -however remote it may be- within common sense. One ceases to be 'contemporaries of' -which puts one in an existence and experience without historical parallel. The context of contemporaneity is contemporaneity itself.

ICT is to be (or not to be) radically unthinkable. Yet, it is a theory of another humanity. It is about this world. It is people's theory. ICT is a metamorphosis among what is thought and nonthought and unthought but is also fundamentally about the temerity of the colonization of the non-/un-/thought within the thought. ICT attempts to understand to grasp how big is infinite, the infinite of thought and action. If one challenges infinity, 'then it is chaos because one is in chaos'; that means that the question or questions (whatever they are) are inaccurately deterritorialized and fundamentally sedentary. ICT "thinks the movement of infinity" (Gil, 2009, p. 97), or the (im)possibility of finitudness of the infinity. ICT implies an understanding of chaos as domestic, as public, as a punctum within the pure luxury of immanence. In such multitude of turfs, ICT needs to be understood as poesis. It plays in the plane of immanence. Since immanence is 'a life,' ICT is 'a life'; ICT “uses what it is not, like it is" as Tse (2017) would put it (p. 67). A life paced by a poesis or a revolution? 'Yes, please' in a full Žižekian way. ICT is, above all, the language for/of doing (Deleuze, 1995). ICT is a poesis that itinerantly throws the subject against the infinite of representation to grasp the omnitude of the real(ity) and the rational(ity), thus mastering the transcendent. Being more poesis than just theory (and not because it is less theory), its itinerant position epitomizes a transcendent nomadography, which is not transcendental. To be more precise, ICT, as Tse (2017) would put it, "awakens what will never end and is housed in it" (p. 104). To rely on Deleuze and Guattari (1987), "it is not death that breaks [the itinerant theorist] but seeing, experiencing, thinking too much life. There's a profound link between signs, events, life and vitalism. Its organisms that die, not life" (p. 143). Such inquiry implies, as Deleuze and Guattari (1987) felicitously unveil, an itinerant theorist that is not just a war machine that judiciously collides with ossified truths and fossilized realities, but its itinerant existence is actually only possible in a permanent theater of war. Needless to say, that ICT is not a cavalier way to grasp history. In this sense, it refuses to "walk backwards towards the future" (Williams, 2013, p. 281). Nor is it just a pale reaction against the way such history has been quasi suffocated by hegemonic and particular counterhegemonic traditions. Although also a concept arguably a geophilosophical one- it goes well beyond an aesthetic wrangle between sedentary theoretical hegemonic, particular counterhegemonic platforms, and nomad(ic) approaches, free from walls, dams, and institutional regression. ICT implies a beyond nomadic inquiry, one that the foci occupies the truly total itinerant 
capacity of space(less)ness, a permanent smooth itinerant position, a perpetual search that whole heartedly aims at saturation yet the saturation of non-saturation. The nomadography of such theory is framed in the nonstop itinerant posture in which creators of poesis seemed to be part of the history of thought but escape from it either in a specific aspect or altogether. ICT challenges the irrelevance of Modern Western Eurocentric disciplinary knowledge as is. ICT attempts to turn curriculum theory against itself as well. It is a philosophy of liberation, which is sentient of the pitfalls of the internationalization dynamics within the curriculum field. The itinerant posture provides powerful space in which to engage in a global conversation that is attentive of the globalisms (Santos, 2008); profoundly aware of the multiplicities of public spheres and subaltern counterpublics (Fraser, 1997); truly attentive to the production of localities (Hardt \& Negri, 2000) and militant particularism (Harvey, 1998), and to the (de)construction of new, insurgent cosmopolitanism (Santos, 2008; Popkewitz, 2007); conscious of the wrangle between the globalized few and the localized rest (Bauman, 1998); and yet profoundly alert to the dangerous hegemony of the English language. Such conversation needs to occur in languages other than English (Darder, 1991).

ICT challenges Modern Western Euroentric abyssal thinking. It challenges one of the fundamental characteristics of abyssal thinking: the impossibility of co-presence of the 'two sides of the abyssal line.' Such theoretical approach is an itinerantology that addresses las heridas abiertas (Anzaldua, 2007) of the colonality of power. Such itinerantology is fully aware que las heridas abiertas cannot be addressed by ignoring "how compressed specific dialectical positions of Marxism are-or specific dialectical positions of specific Marxisms- thus obliterating fair and inclusive analysis" (Paraskeva \& Sussekind, 2018). That is, ICT is a form of decolonial thinking that recognizes an ecological co-existence of varying epistemological forms of knowledge around the world paying attention to knowledges and epistmologies largely marginalized and descredit in the current world order" (Zhao, 2019, p. 27).

ICT is not merely an invocation or evocation (Schubert, 2017, p. 10). ICT touches the 'real' nerve (Dabashi, 2015) by challenging both dominant and specific counterdominant traditions within the Modernity Western Eurocentric epistemological matrix as part of the epistemicide. However, as a future for the field, ICT alerts for the need to walk away from all forms of romanticism regarding the non-Modern non-Western non-Eurocentric epistemes. ICT is not a nationalistic theoretical platform. ICT fights any form of indigenoustude (Paraskeva, 2011); it is about decolonizing native narratives by "considerin the relationship of language to power and also to empowerment" (Mallon, 2012, p. 3). In so doing, it reacts against epistemological blindness, as it opens the veins of a complex beast, dissects its strokes and counter strokes (Janson \& Paraskeva, 2016), denounces and announces the involution phase of the field as well as its occidentotic fungus, and offers just ways out of it, through a just pluriversal epistemological reading and doing of the wor(l) d. ICT reacts against the "the violent power of the identical that becomes invisible" as Byung-Chul (2018) would put it (p. 10); it reacts against the fading of otherness in an era in which "the negativity of the other gives place to the positivity of the identical” (Byung-Chul, 2018, p. 10). In ICT terms, the identical is pornographic, 
that is "[in] pornography, all bodies resemble each other, they break down into identical body parts. Stripped of all language the body is reduced to the sexual that knows no other difference than sexual" (Byung-Chul, 2018, p. 15). ICT is a call against an "ontic deficit" that permeates society (Byung-Chul, 2018, p. 13). Its pluriverse nature smahes the obscene link between the identical and the identical" (Byung-Chul, 2018, p. 16).

ICT move towards a just blend beween experiencies and expectations, an alternative logic of utopianism that re-directs towards a "possiblity to wait with hope" (Santos, 1999, p. 213), thus making the new utopia -a decolonial one, utopian otherwise- the desperate realism of a waiting that allows itself to fight for the content of waiting, not in general but in the exact place and time in which it is" (Santos, 1999, p. 213). Thus, hope, in ICT terms, "does not lie in a general principle which provides for a general future. It resides instead in the possibility of creating fields of social experimentation where it is possible to resist locally the evidences of inevitability, successfully promoting alternatives that seem utopian at all times and places except those in which they actually occurred" (Santos, 1999, p. 213). Hence, ICT reignites the utopia, since "the existence does not exhaust the possibilities of existence and therefore there are alternatives susceptible of surpassing what is critical in what exists" (Santos, 1999, p. 198); yet a different utopian logic though not because "the utopian pragmatism disappeared, but because it is not what it used to be" (Gil, 2009, p. 18), nor that it can't be. An alternative frame toward alternative utopias cannot be framed -and subjugated- within a matrix that actually will never allow the materialization of such utopia. ICT is not a re-invention or a re-habilitation of past utopianist(s) logic(s), although such constitutes some of its pillars. In Darder's (2018) terms, ICT "is meant to guide us in transforming our labor into a living praxis of global cognitive justice" (p. XIII).

ICT implies one to "detheorize reality as the only way to reinvent it" (Santos, 1995, p. 513). It is an epistemological declaration of independence (Paraskeva, 2019). It is, thus, the pluriversal rubber stamp of the death of the logic through which Modern Western Eurocentric platforms imposed a mono-episteme. ICT is not a drone theory though; it doesn't speak for the other. ICT is chaos and its rythms a chaos that "inaugurates the appearance of things not because it engenders them, but because it withdraws" (Gil, 2018, p. 376). ICT thus offers a way out of the involution volt, out of occidentosis. In Jupp's (2017) terms, ICT is call to "preserve and advance the historically specific and localized knowledges and languages that underlie cognition -and through cognition cultural practices and social relationsrepresent the fundamental struggle for social justice" (p. 5). ICT dissects chaos as normalcy that "presides over the order of the world; as what it establishes because it withdraws -and in withdrawing, allows the emergence of thinkable things because they are discernible, differentiated" (Gil, 2018, p. 376). Chaos, and ICT in this sense, "ends with the unthinkable" (Gil, 2018, p. 376). Therefore, ICT is emancipatory, inaugurating a "paradigmatic transition from a reactionary (n)eugenic cosmic capacity towards a chaosmic capacity, one that imposed alterative forms of sociability rather than one form of sociability" (Santos, 1995, p. x). Chaos is bipolar, a consequence and a beginning, so as curriculum. In this context, ICT challenges 
the cultural politics of denial, which produces a radical absence, the absence of humanity, the modern sub-humanity (Santos, 2015, p. 30). Such new theoretical task understands that modern humanity is not conceivable without a modern subhumanity (Santos, 2014), and that the denial of a part of humanity is sacrificial, in that it is the condition for the other part of humanity, which considers itself as universal. ICT, thus, aims precisely to 'a general epistemology of the impossibility of a general epistemology.' Such radical co-presence, Santos (2007b) argues, -the begin-anew (Darder, 2018) - pushes one towards a postabyssal momentum, a postabyssal epistemology, which spans an ecology of knowledges (Santos, 2007b, p. 40). Consequently, there is "a call for the democratization of knowledges that is a commitment to an emancipatory, non-relativistic, cosmopolitan ecology of knowledges, bringing together and staging dialogues and alliances between diverse forms of knowledge, cultures, and cosmopologies in response to different forms of oppression that enact the coloniality of knowledge and power" (Santos, 2007a, p. XIV). ICT respects three fundamental pillars: "(1) learning that the South exists, (2) learning to go to the South, and (3) learning from and with the South (Santos, 2015). That is, in order to learn from the South we must first of all let the South speak up for what best identifies the South is the fact that has been silenced" (Santos, 1995, p. 510).

Postabyssal thinking implies a radical break with modern Western ways of thinking and acting. Postabyssality "is always coknowledge emerging from process of knowing-with rather than knowing-about" (Santos, 2018, 147). While an overt challenge against the colonialism of English language (Darder, 1991), as well as a call to arms against all other forms of linguistic colonialism perpetrated by other modern Western languages (Paraskeva, 2011), ICT is also an alert against what Ahmad (2008) coined as third world nationalisms and modern Western internationalization and internationalisms. Such radical break doesn't mean slurring specific modern Western impulses. The ecology of knowledges needs to be seen as a "destabilizing collective or individual subjectivity endowed with a special capacity, energy, and will to act with clinamen experimenting with eccentric or marginal forms of sociability or subjectivity inside and outside Western modernity, those forms that have refused to be defined according to abyssal criteria" (Santos, 2007b, p. 41). ICT is a destabilizing epistemology that aims to defamiliarize the canonic tradition of monocultures of knowledge (Santos, 2014). What is crucial within the ecology of knowledges is what Santos (2007b) calls "action-with-clinamen" (p. 40), which "does not refuse the past; on the contrary, it assumes and redeems the past by the way it swerves from it" (p. 41). In claiming a commitment of the radical copresence, ICT is fully engaged in such ecology of knowledges, and the challenge of an itinerant curriculum theorist is to "unpuzzle" the nexus of physical-metaphysical.

That is, we are bodies; we are not institutions, although a schizophrenic system institutionalizes us. Our task is to unmask why we do not teach this and how can we teach this. This 'this' is not just physical, it is also metaphysical. In that sense, ICT is an ethical take. I argue though that ICT pushes above and beyond postabyssality towards a non-abyssal punctum since it not only challenges the modern Western cult of abyssal thinking but also attempts to dilute such fictional vacuum 
between the lines. ICT is not just an act of resistance, but of re-existence (Walsh, 2018) at the metaphysical level. ICT undeniably is an epistemological declaration of idependence. It is a "liberated zone" (Santos, 2018, p. 31). In this sense, ICT is a dis/positional thinking concerned "for viewing educational phenomena from alternative perspectives that are nor method driven, but instead derived from insights of a disposition that seeks to disentangle schlarship from its traditional dependence on formalities" (Reyonolds \& Webber, 2016, pp. 5-6).

The struggle against modern Western abyssal thinking is not just a policy matter. It is also above and beyond that. It is an existential and spiritual question so eloquently advocated by Huebner $(1966 ; 1959)$ and Macdonald (1966a; 1966b) last century. As I keep reminding, Huebner was indeed the avant la lettre intellectual, advocating among other crucial issues for the urgent need for a new language to dissect the educational phenomena. In Huebner $(1966 ; 1959)$ terms, such abyssality is traped within a dangerous eugenic despotic anthrocentric semiology. In one of his more brilliant works (1966), he insisted that curriculum language is immersed in two tyrannical myths: "one is that of learning -the other that of purpose, almost magical elements the curriculum worker is afraid to ignore, let alone question" (p. 10). He argues that "learning is merely a postulated concept, not a reality and objectives are not always needed for educational planning" (p. 10). For Huebner, the major problem in the world of education, "which has been short-circuited by behavioral objectives, sciences, and learning theory, was the fact that we were not dealing with the autobiography, we were not dealing with life and inspiration" (Huebner, 2002, Tape 1). The language of education is full of "dangerous and non- recognized [and unchallenged] myths" (Huebner, 1966, p. 9), which makes it impossible to question whether the "technologists maybe were going in the wrong direction" (Huebner, 2002, Tape 1). This becomes much more complex and alarming in a society that is facing the fact that "the problem is no longer one of explaining change, but of explaining nonchange" (Huebner, 1967, p. 174), and that a human being, by his transcendent condition, "has the capacity to transcend what he is to become, something that he is not" (p. 174). Furthermore,

For centuries the poet has sung of his near infinitudes; the theologian has preached of his depravity and hinted of his participation in the divine; the philosopher has struggled to encompass him in his systems, only to have him repeatedly escape; the novelist and dramatist have captured his fleeting moments of pain and purity in never-to-be-for- gotten aesthetic forms; and the [man] engaged in the curriculum has the temerity to reduce this being to a single term-learner (Huebner, 1966, p. 10).

However, the struggle against the Western Cartesian model cannot signify the substitution of Cartesian model for another one. Also, the task is not to dominate such model or to rap with a more Eurocentric humanistic impulse. The task is to pronounce its last words, to prepare its remains for a respectful funeral. The task is not to change the language and concepts, although that is crucial. The task is to terminate a particular hegemonic geography of knowledge, which promotes an epistemological euthanasia. 
ICT's non-abyssality is "informed by its epistemological rupture from the coloniality of power and disaffiliation with hegemonic dogma, a process that liberates our field of consciousness, opening the way for resurgences of subaltern perspectives, new expressions of solidarity, and the powerful regeneration of that political force necessary for transforming the social and material conditions of our present existence -not only in the mind but also in the flesh" (Darder, 2018, p. xIV). ICT is a "deliberate disrespect of the canon, a struggle against epistemological orthodoxy" (p. xxv), and it attempts "to bring scientific knowledge face-to-face with nonscientific, explicitly local knowledges, knowledges grounded in the experience of the leaders and activists of the social movements studied by social scientists" (p. xxv). This is the very core of its nutritive faculty, to use Agamben's (1999) Aristotelic approach. An itinerant curriculum theory is an exercise of "citizenship and solidarity" (p. Xxv) and, above all, an act of social and cognitive justice. It is, as Žižek (2006) would put it, the very best way to understand how reality can explode in and change the real.

I am not claiming a way out that will please everybody. In fact, "a coherent theory is an imposed theory which falsely mythologizes a pseudo-scientific process that has no more to do with real science than astrology does" (Quantz, 2011). ICT is, however, a consequence of the perpetual lack of a dominant praxis of a "perfect just teaching and learning," as Tse (2017) would say (p. 284). An itinerant theoretical approach dares to violate the methodological canon and attempts to go beyond some interesting (counter)dominant clashes to overcome some dead ends and screaming silences, yet it is an epistemological struggle within the insurgent cosmopolitanism platforms (Sousa Santos, 2008) both inside and beyond the Western dominant cartography (2011a). ICT is to de-link towards a polycentric world, as Amin (1990) would put it. There is no question, Darder (2018) sternly claims, that the post-abyssal terrain of itinerant curriculum constiutes a complex and challenging political project, yet one that offers us political solace, philosophical inspiration, and pedagogical nourishment on a long and arduous journey. ICT

entails navigating dialectically the often-murky realm of dominant/subordinate relations of power. Yet, it is precisely by consistently traversing the turbulence of this dialectical tension that we become politically primed to ruthlessly critique oppression in ways that prevent us from inadvertently collapsing back into oppressive binary contradictions, from which we ourselves must constantly struggle to emerge anew. And further, it is only through such sustained labor and unwavering commitment to denounce the epistemological totalitarianism of our times that we can garner together the moral indignation and political will to announce new ways of knowing, loving and being -beyond the abyssal divide of recal- citrant racisms and neoliberal devastation. (Darder, 2018, pp. XIV-Xv)

In this regard, an itinerant theoretical path without floodgates because the best sentinels always have no floodgates (Couto, 2008). In so doing, the itinerant curriculum theory honors a legacy of accomplishments and frustrations, understanding that de-linking will always be to make theory, a just theory. To delink and decolonize, while honoring the legacy of the radical critical path taking 
it into a different level, it is also a decolonial attempt "to do critical theory" (Kellner, 1989, p. 2). Respecting the legacy of such generation of the utopia, such decolonial attempt needs cannot ignore the rich legacy of such group of phenomenal utopists, and needs to keep swimming through a radical critical river yet reaching out and recognizing endless tributaries and other rivers and tributaries beyond the river bed of such Modern Western Eurocentric river and, in doing so, produce a new logic towards a new needed utopia. ICT it is a just way to "to ruthlessly problematize and rethink consciousness or to begin anew, by way of our subaltern engagements of Marx's unfinished political economic project, in an effort to deepen and expand its emancipatory vision, namely, the liberation of our humanity -but only now through the complexity of multi-centered epistemological lenses able to withstand the everchanging character our cultural formations and political manifestations" (Darder, 2018, p. XIII). ICT is a heretopian theory. It is people's theory.

Recibido: 11-12-2019; ACEPTADO: 17-2-2020 


\section{REFERENCES}

Agamben, G. (1999). “Absolute Immanence,” in J. Khalfa (ed.) An Introduction to the Philosophy of Gillen Deleuze. London: Continuum, pp. 151-69.

Agamben, G. (2005). The state of exception. Chicago: Chicago University Press.

Ahmad, J. (1984). Occidentosis. A Plague from the West. Iran: Mizten Press.

Ahmad, A. (2008). In Theory. Classes, Nations, Literatures. London: Verso.

Amin, S. (1990). Delinking: Towards a Polycentric World. London: Zedbooks.

Anzaldua, G. (2007). Borderlands. La Frontera. The New Mestiza. S. Francisco: Aunt Lute Books.

Apple, M. (1979). Ideology and Curriculum. New York: Routledge.

Auge, M. (1994) (2003). Não-Lugares: introdução a uma antropologia da supermodernidade. Campinas: Papirus Editora.

Bauman, Z. (1998). Globalization. The Human Consequences. London: Blackwell Publishers.

Berardi, 'F. (2012). The Uprising. On Poetry and Finance. Los Angeles: Semiotext(e).

Byung-Chul, Han (2018). A Expulsao do Outro. Lisboa: Relogio D’Agua.

Couto, M. (2008). Terra Sonambula. Lisboa: Leya.

Darder, A. (1991). Culture and the power in the classroom. Boulder, CO: Paradigm.

DArder, A. (2018). "Ruthlessness and the Forging of Liberatory Epistemologies: An Arduous Journey," in J. Paraskeva. Curriculum Epistemicides. New York: Routledge.

Deleuze, G. (1995). The Logic of Sense. New York: Columbia University Press.

Deleuze, G. \& Guattari, F. (1995) (1987). A Thousand Plateaus. Capitalism and Schizophrenia. Minneapolis: University of Minnesota Press.

Deleuze, G. (1990). Pourparlers. Paris: Les Editions de Minuit.

Deleuze, G. \& Guattari, F. (1987). A Thousand Plateaus. Capitalism and Schizophrenia. Minneapolis: University of Minnesota Press.

Eco, U. (1984). Proscript to the Name of the Rose. New York: Harcourt, Brace and Jovanovich.

Fraser, N. (1997). Justice Interrupts. Critical Reflections on the 'Postcolonialist' Condition. New York: Routledge.

GiL, J. (2018). Caos e Ritmo. Lisboa: Relógio D’Água.

GIL, J. (1998). Metamorphoses of the Body. Minnesota: University of Minnesota Press.

Gis, J. (2009). Em Busca da Idenitidade. O Desnorte. Lisboa: Relógio D’Água.

Gil, J. (2010). O Devir-Eu de Fernando Pessoa. Lisboa: Relógio D’Água.

Gough, N. (2000). "Locating Curriculum Studies in the Global Village," Journal of Curriculum Studies, 32 (2), pp. 329-42.

Hardt, M. \& Negri, T. (2000). Empire. Cambridge: Harvard University Press.

Harvey, D. (1998). "What's Green and Makes the Environment go Round?," in F. Jameson and M. Miyoshi (eds.) The Cultures of Globalization. Post-Contemporary Interventions. Duke University Press, pp. 327-355. 
Huebner, D. (1959). From Classroom Action to Educational Outcomes. An Exploration in Educational Theory. Madison: University of Wisconsin- Madison.

Huebner, D. (1966). "Curricular Language and Classroom Meanings," in J. Macdonald \& R, Leeper. (eds.). Language and Meaning. Washington: ASCD.

Huebner, D. (2002). Tape \# 1, recorded at 3718 Seminary Rd, Alexandria, VA 22304. Washington. USA.

Jin, H. (2008). The Writer as Migrant. Chicago: The University of Chicago Press.

Jupp, J. (2017). “Decolonizing and De-Canonizing Curriculum Studies.” Journal for the American Association for the Advancement of Curriculum Studies. 12, (1), pp. 1-22, pp. 1-25.

Kellner, D. (1989). Critical Theory, Marxism and Modernity. Baltimore: The John Hopkins University Press.

Khalfa, J. (1999). “Introduction,” in J. Khalfa (ed.) An Introduction to the Philosophy of Gillen Deleuze. London: Continuum, pp. 1-6.

Kliebard, H. (1968). “The Curriculum Field in Retrospect," in P. Witt (ed.). Technology and Curriculum. New York: Teachers College Press, pp., 69-84.

Krug, E. (1969). The Shaping of the American High School, 1880-1920. Madison: The University of Wisconsin Press.

Mallon, F. (1994). The Promise and Dilemma of Subaltern Studies: Perspectives from Latin American History. American Historical Review, 99, pp. 1491-515.

Macdonald, J. (1966a). "Language, Meaning and Motivation: An Introduction," in J. Macdonald \& R. Leeper (eds.). Language and Meaning. Washington: ASCD, pp. 1-7.

Macdonald, J. (1966b). “The Person in the Curriculum,” in H. Robinson (ed.) Precedents and Promise in the Curriculum Field. New York: Teachers College, Columbia University, pp. 38-52.

Merlau-Ponty, M. (1973). The Prose of the World. Evanston: Northwestern University Press.

Mignolo, W. (2018). "The Invention of the Human and the Three Pillars of the Coloniality Matrix of Power." In Catherine Walsh and Walter Mignolo. On Decoloniality. Concepts, Analytics, Praxis. Durham: Duke University Press, pp. 153-176.

Moreira, M. A. (2017). “And the Linguistic Minorities Suffer What They Must?': A Review of Conflicts In Curriculum Theory Through the Lenses of Language Teacher Education?" Journal for the American Association for the Advancement of Curriculum Studies. 12, (1), pp. 1-17.

O’Brien, M. \& Penna, S. (1999). Theorizing Welfare. London: Sage.

Oliverra, Ines B. (2017). "Itinerant Curriculum Theory Against the Epistemcide. A Dialogue Between the Thinking of Santos and Paraskeva." Journal for the American Association for the Advancement of Curriculum Studies. 12, (1), pp. 1-22.

Paraskeva, J. (2011). Conflicts in Curriculum Theory. Challenging Hegemonic Epistemologies. New York: Palgrave.

Paraskeva, J. (2017). The Epistemicide. New York: Routledge.

Paraskeva, J. (2018). Towards a Just Curriculum Theory. The Epistemicide. New York: Routledge.

Paraskeva, J. (2019). “¿Qué sucede con la teoría crítica (currículum)? La necesidad de sobrellevar la rabia neoliberal sin evitarla”. Rosa V. Recio (comp.) Reconocimiento y Bien Comun en Educacion. Madrid: Morata, 191-230. 
Paraskeva, J. \& Sussekind, M.L. (2018). "Contra a Cegueira Epistemológica nos Rumos da Teoria Curricular Itinerante.” Educação e Cultura Contemporânea, v. 15, pp. 54-85.

Pessoa, F. (2010). Textos Filosóficos, volume II. Lisboa: Nova Ática.

Pessoa, F. (2014). Livro do Desassossego. Lisboa: Assirio \& Alvim.

PInar, W. (2000). "Introduction: Toward the internationalization of curriculum studies," in D. Trueit, W. Doll Jr., H. Wang, and W. Pinar (eds.) The internationalization of curriculum studies. New York: Peter Lang, pp. 1-13.

PInar, W. (2004). What is Curriculum Theory? Mawah: Lawrence Erlbaum Associates Publishers.

Pinar, W. (2013). Curriculum studies in the United States: Present circumstances, intellectual histories. New York, NY: Palgrave Macmillan.

Pokwewitz, Th. (1978). "Educational Research: Values and Visions of a Social Order." Theory and Research in Social Education, vol. 4, (4), p. 28.

Popkewitz, Th. (2007) (2007). Cosmopolitanism and the Age of School Reform. Science, Education, and Making Society, by Making the Child. New York: Taylor and Francis.

Quantz, R. (2011). Rituals and Students Identity in Education: Ritual Critique for a New Pedagogy. New York: Palgrave.

Reynolds, W. \& Webber, J. (2016). “Introduction: Curriculum Dis/positions,” in William Reynold and Julie Webber (eds.) Expanding Curriculum Theory. Dis/positions and Lines of Flight. New York: Routledge, pp. 1-11.

SAID. E. (2005). "Reconsiderando a Teoria Itinerante," in Manuela Sanches (org.) Deslocalizar a Europa. Antroplogia, Arte, Literatura e História na Pós-Colonialidade. Lisboa: Cotovia, pp. $25-42$.

Santos, B. (1995). Towards a New Common Sense. Law, Science and Politics in the Paradigmatic Transition. New York: Routledge.

Santos, B. (1999). "Porque é tão difícil construir uma teoria crítica?" Revista Crítica de Ciencias Sociais, n. ${ }^{\circ}$ 54, Junho, pp. 197-215.

Santos, B. (2007a). Another Knowledge is Possible. London: Verso.

Sousa Santos, B. (2007b). "Beyond Abyssal Thinking. From Global Lines to Ecologies of Knowledges." Review, xxx (1), pp. 45-89.

Santos, B. (2008). "A universidade no seculo xxi. Para uma reforma democratica e emancipatoria da universidade," In B. Sousa Santos \& N. de Almeida Filho (eds.), A universidade no seculo XXI. Para uma universidade nova (pp. 13-106). Coimbra: Centro de Estudos Sociais.

Santos, B. (2015). If God Were a Human Rights Activist: Human Rights and the Challenge of Political Theologies. Is Humanity Enough? Stanford; Stanford University Press.

Santos, B. (2014). Epistemologies of the South: justice against epistemicide. Boulder: Paradigm.

Santos, B. (2018). The End of the Cognitive Empire. Durham: Duke University Press.

Schubert, W. (1986). Curriculum. Perspective, Paradigm and Possibility. New York: MacMillan Publishing Company.

Schubert, W. (2017). "Growing Curriculum Studies: Contributions of João M. Paraskeva." Journal for the American Association for the Advancement of Curriculum Studies. 12, (1), pp. 1-22, pp. 1-21. 
Süssekind, M. ${ }^{2}$ L. (2017). "Against Epistemological Fascism. A Reading of Paraskeva’s Itinerant Curriulum Theory." Journal for the American Association for the Advancement of Curriculum Studies. 12, (1), pp. 1-18.

Tse, C. (2017). Chuang Tse. Lisboa; Relogio D’Agua.

Tyack, D. (1974). The One Best System. A History of American Urban Education. Cambridge: Harvard University Press.

Walsh, C. \& Mignolo, W. (2018). "Introduction," in Catherine Walsh and Walter Mignolo, On Decoloniality. Concepts, Analytics, Praxis, Durham: Duke University Press, pp. 1-12.

Walsh, C. (2012). 'Other' Knowledges, 'Other' Critiques Reflections on the Politics and Practices of Philosophy and Decoloniality in the Other America. Transmo- dernity. Journal of Peripheral Cultural Production of the Luso-Hispanic World, 1 (3), pp. 11-27.

Williams, R. (2013). Long Revolution. London: Verso.

Zhaо, W. (2019). China's Education, Curriculum Knowledge and Cultural Inscriptions. Dancing with the Wind. New York: Routledge.

ŽıžEK, S. (2006). Bem-Vindo ao Deserto do Real. Lisboa: Relogio D’Agua. 
